\title{
Pengaruh Konseling Kelompok Values Clarification Terhadap Peningkatan Sikap Toleransi Beragama
}

\author{
I Made Sonny Gunawan ${ }^{1}$, Made Gunawan², Reza Zulaifi ${ }^{3}$ \\ ${ }^{123}$ Fakultas Ilmu Pendidikan dan Psikologi Universitas Pendidikan Mandalika \\ email: imadesonnygunawan@undikma.ac.id
}

\begin{abstract}
The purpose of this study was to analyze the effect of group counseling values clarification modeling techniques on increasing religious tolerance in students. This study uses a repeated measure experimental design with pretest and multiple posttest designs. The subjects in this study were 5 students class VII at Mts. Madrasatul Qur'aniyah, West Lombok Regency. Data were collected using a tolerance attitude questionnaire. Data analysis used repeated measure ANOVA statistic. The results of this study revealed that the values clarification group counseling with modeling techniques through short videos was effective for increasing inter-religious tolerance among students at Mts. Madrasatul Qur'aniyah.
\end{abstract}

Keywords: Group counseling, values clarification, modelling, tolerance attitude

\begin{abstract}
Abstrak
Tujuan dari penelitian ini untuk menganalisis pengaruh konseling kelompok values calrification teknik modelling terhadap peningkatan sikap toleransi beragama pada siswa. Penelitian ini menggunakan rancangan eksperimen repetead measure dengan desain pretest and multiple posttest design. Subyek dalam penelitian ini sebanyak 5 orang siswa kelas VII di Mts. Madrasatul Qur'aniyah Kabupaten Lombok Barat. Data dikumpulkan dengan menggunakan kuesioner sikap toleransi. Analisis data menggunakan statistik repeated measure ANOVA. Hasil dari penelitian ini mengungkapkan bahwa konseling kelompok values clarification dengan teknik modeling melalui video pendek efektif untuk meningkatkan sikap toleransi antar umat beragama pada siswa di Mts. Madrasatul Qur'aniyah.
\end{abstract}

Kata kunci: Konseling kelompok, values clarification, modelling, sikap toleransi

\section{PENDAHULUAN}

Bersikap toleran merupakan salah satu solusi untuk menghindarkan diri dari perselisihan. Sikap toleransi harus menjadi suatu kesadaran pribadi yang selalu dibiasakan dalam wujud interaksi sosial (Djollong \& Akbar, 2019). Toleransi dapat dijelaskan sebagai bentuk kemurahan, kasih sayang, pengampunan dan perdamaian. Adapun jika dikaitkan dengan nilai religius maka toleransi dapat diartikan sebagai kemurahan, kasih sayang, dan perdamaian antar pemeluk agama lainnya. Sikap toleransi antar umat beragama secara tidak langsung dapat menyebabkan seseorang menjadi lebih dekat dan mampu merasakan arti kebersamaan dalam perbedaan (Ling \& Dariyo dalam Nuswantari, 2018).

Lebih lanjut, toleransi juga dikatakan sebagai sikap menghargai, menghormati keyakinan orang lain tanpa memerlukan persetujuan (Abdussami, 2003). Toleransi dalam pergaulan hidup antar umat beragama, didasarkan kepada setiap agama menjadi tanggung jawab pemeluk agama itu sendiri dan mempunyai bentuk ibadat dengan sistem yang dibebankan terhadap pemeluk agama tersebut.
Adapun atas dasar itu, maka toleransi dalam pergaulan hidup antar umat beragama bukanlah toleransi dalam masalah-masalah keagamaan melainkan, perwujudan dari sikap keberagamaan pemeluk suatu agama dalam pergaulan hidup antara orang yang tidak seagama, dalam masalah-masalah kemasayarakatan atau kemaslahatan umum (Munawar, 2003).

Toleransi lahir dari sikap menghargai diri (self-esteem) yang tinggi dan muncul pada orang yang telah memahami kemajemukan secara optimis-positif. Jadi toleransi beragama adalah sikap memahami, menghormati dan menghargai keyakinan yang dimiliki oleh orang lain serta dengan sukarela tanpa paksaan, membiarkan mereka beribadah sesuai dengan kepercayaannya. Lebih lanjut, sikap memahami, menghormati, menghargai dan membiarkan keyakinan tersebut adalah sebagai bentuk pemahaman terhadap adanya perbedaan yang tidak dapat dipungkiri keberadaannya di dalam kehidupan bermasyarakat (Utami, 2018).

Sullivan \& Transuc (dalam Doorn, 2014) mengidentifikasi beberapa faktor yang 
dapat mempengaruhi individu untuk bertoleransi: (1) pendidikan, adalah hal pertama yang menjadi faktor penentu seseorang dapat bertoleransi, orang yang memiliki pendidikan tinggi akan lebih dapat menghargai orang lain (bertoleransi) dengan masyarakat umum dari pada orang yang memiliki pendidikan rendah; (2) norma demokrasi, yang berarti adanya suatu dukungan terhadap prinsip-prinsip demokrasi secara umum seperti hak dalam kalangan minoritas, persamaan hak dibawah payung hukum dan kebebasan berbicara (Sullivan et al., 1982); (3) ancaman, hal ini telah diidentifikasi sebagai salah satu penyebab seseorang tidak dapat bertoleransi. Gibson (2006) menjelaskan seseorang yang merasa terancam dengan sesuatu cendrung tidak dapat mentoleransi hal tersebut, dimana mereka dapat bertindak diluar kendali dan tidak dapat bertoleransi demi terbebas dari ancaman yang didapat; dan (4) faktor pribadi, di mana keperibadian seseorang juga dapat menjadi penentu orang dapat bertolernasi atau tidak, ketika psikologis seseorang tidak normal cendrung akan memperlakukan seseorang dengan tidak baik.

Lebih lanjut, toleransi sebagai realitas juga dibentuk oleh nilai dalam masyarakat itu sendiri. Unsur-unsur toleransi menurut Hasyim (1997) adalah (1) mengakui hak setiap orang, (2) menghormati keyakinan orang lain, (3) agree in disagreement (setuju di dalam perbedaan), dan (4) saling mengerti. Toleransi dalam beragama merupakan salah satu nilai karakter yang sangat penting untuk di miliki oleh para siswa di sekolah. Adapun nilai toleransi sangat berhubungan erat dengan nilai religius yang dapat membentuk sikap dan perilaku patuh terhadap perintah agama. Namun pada kenyataannya masih banyak dijumpai permasalahan terkait dengan intoleran antara umat beragama yang dilakukan oleh siswa di sekolah maupun dilingkungan tempat tinggalnya. Sikap intoleran tersebut digambarkan dengan sikap anarkis dan apatis terhadap pemeluk agama yang berbeda sehingga kekerasan seringkali terjadi seperti tindakan bullying, perkusi, dan sampai menjadi rasisme.
Bentuk dari intoleran antar umat beragama yang banyak dilakukan oleh siswa adalah mereka hanya mau bergaul dengan teman yang seagama dan seiman (Dojosantoso dalam Surur, Septiani \& Trianawati, 2018). Selain itu bentuk dari tindakan intoleran antar umat beragama yang banyak dilakukan oleh siswa adalah kurang hormat, kurang sopan, menghina keyakinan seseorang, dan melakukan tindakan anarkis (Mujahidin, Rahman \& Aqilah, 2020). Gambaran dari sikap intoleran antar umat beragama tersebut merupakan ciri-ciri dari degradasi moral yang di alami oleh banyak siswa saat ini.

Adapun permasalahan intoleran antar umat beragama merupakan fenomena yang banyak terjadi di sekolah-sekolah. Hal tersebut sejalan dengan hasil penelitian yang dilakukan oleh Widyaningsih, Zamroni \& Zuchdi (2014) di mana mereka menyatakan jika banyak ditemukan siswa yang melakukan pelanggaran nilai-nilai moral baik itu di sekolah maupun di lingkungan masyarakat, dan salah satu bentuk pelanggaran yang sering di jumpai adalah terkait dengan masalah intoleransi antar umat beragama.

Permana, Rachmat \& Ismail (2014) serta Mujahidin, Rahman \& Aqilah, (2020) juga mengungkapkan jika masalah intoleran antar umat beragama di kalangan pelajar sangat meresahkan. Permasalah tersebut tidak hanya terjadi dikalangan siswa sekolah menegah namun sudah merambat kedalam perguruan tinggi (Akbar, 2018; Bahari, 2010). Permasalahan ini harus segera dicarikan solusinya agar tidak terjadinya disintegrasi sosial. Adapun, untuk meminimalisir hal tersebut maka diperlukan suatu nilai, sikap, keyakinan ataupun aturan yang dapat menjadi pedoman bagi individu.

Dalam hal ini nilai religius dianggap sebagai salah satu kekuatan untuk membentuk karakter positif siswa di sekolah yang sangat erat kaitannya dengan sikap toleransi antar umat beragama. Nilai religius dapat terlihat dalam wujud perilaku yang tampak dari diri indivdu seperti tawadhu, hormat, dan sopan santun, beriman dan bertakwa kepada Tuhan, sabar, ikhlas, dan selalu bersyukur (Wati \& Arif, 2017). Berdasarkan pendapat tersebut 
dapat dikatakan jika penanaman nilai-nilai religius sangat penting bagi siswa sebagai pedoman hidup yang baik. Selain itu nilai religius juga dapat mengarahkan siswa untuk mampu mengahargai sesama umat beragama atau saling bertoleransi dan hidup rukun dalam damai.

Lebih lanjut, untuk meminimalisir permasalahan tersebut dibutuhkan suatu pendekatan yang kompleks dan dapat menumbuhkan nilai-nilai positif dalam diri individu. Pendekatan yang dianggap cocok untuk membantu siswa di dalam menumbuhkan nilai toleransi beragama adalah values clarification dengan teknik modelling yang menekankan pada nilai-nilai religius. Pendekatan ini digunakan untuk membantu siswa menemukan nilainya di dalam keragaman nilai, agar mereka hidup lebih baik, lebih bermakna, dan agar dapat menghindari masalah yang diakibatkan oleh kurangnya kejelasannya nilai (Kirschenbaum, 2000).

Pendekatan values clarification merupakan suatu konsep pemikiran yang berfokus pada "tujuan hidup" (Gunawan, 2020). Selain itu, values clarification juga dirancang untuk membantu individu agar dapat membuat keputusan dalam pilihan hidup yang rumit sehingga dapat menjelaskan dan mengaktualisasikan tujuan, arah dan prioritas nilai mereka. Values clarification dikatakan sebagai proses belajar yang dilakukan dengan menggali, memperjelas nilai-nilai dan menetapkan rencana tindakan yang didasarkan kepada pemahaman dan pengetahuan terhadap nilai-nilai yang dianutnya. Kirschenbaum (2013) menyatakan bahwa values clarification adalah pendekatan berupa strategi pembelajaran yang digunakan untuk fokus pada proses menghargai daripada isi dari nilai. Dari pejelasan tersebut dapat disimpulkan bahwa values clarification adalah pendekatan yang menekankan pada proses belajar untuk menggali potensi diri dalam menemukan nilainilai melaui perilaku, emosi dan kognisi.

Lebih lanjut, menurut Stewart, Tong, Siemens, Alibhai, Pickles, Robinson \& Brundage (2012) mengatakan jika pendekatan values clarification dapat membantu individu di dalam mempersiapkan diri untuk pengambilan keputusan yang lebih baik dari pengembangan sosial dan emosionalnya. Senada dengan pendapat tersebut Pieterse, Vries, Kunneman, Stiggelbout \& Steward (2013) menyatakan bahwa pendekatan values clarification dapat mengkonstruk pikiran positif terkait dengan keyakinan atau nilainilai dalam diri individu yang sesuai dengan kenyataannya. Sedangkan Witteman, et al (2016) juga mengungkapkan bahwa secara eksplisit values clarification merupakan pendekatan yang direkomendasikan untuk membantu individu dalam menentukan keputusannya terkait dengan masalah nilai, walaupun dari banyak penelitian values clarification menggunakan desian yang berbeda-beda.

Adapun dalam penelitian ini pendekatan values clarification diterapkan melalui proses konseling kelompok. Lebih lanjut, dalam penelitian ini digunakan tahapantahapan konseling kelompok yang dikembangkan oleh Corey (2012) dimana konseling kelompok dibagi menjadi empat tahap, yaitu: (1) tahap orientasi, (2) tahap transisi, (3) tahap kerja dan (4) tahap terminasi. Selain itu dimungkinkan untuk menyisipkan tiga tingkat dan tujuh tahapan konsep values clarification ke dalam tahap kegiatan (Kirschenbaum, 2013). Tujuh tahap dalam tiga tingkatan values clarification terdiri dari: (1) Tingkat menghargai terdiri dari (a) menghargai nilai, dan (2) menegaskan nilai; (2) Tingkat memilih terdiri dari (a) memunculkan alternatif, (b) memunculkan konsekuensi, dan (c) kebebasan memilih; dan (3) Tingkat bertindak yang terdiri dari (a) bertindak sesuai nilai dan (2) bertindak secara konsisten.

\section{METODE PENELITIAN}

Penelitian ini merupakan penelitian kuantitatif dengan metode penelitian eksperimen. Metode penelitian eksperimen dipilih karena untuk melakukan pengujian tentang suatu ide, apakah ide tersebut memiliki hubungan sebab-akibat atau mempengaruhi terhadap hasil (variabel independen). Creswell (2015) mengungkapkan bahwa eksperimen adalah rancangan kuantitatif terbaik yang 
dapat digunakan untuk menetapkan kemungkinan sebab-akibat. Hal ini sesuai dengan tujuan dalam penelitian ini yaitu untuk meneliti hubungan sebab-akibat dari dua variabel yaitu konseling kelompok values clarification dengan teknik modelling terhadap sikap toleransi antar umat beragama.

Penelitian ini menggunakan rancangan eksperimen modifikasi repetead measure dengan desain pretest and multiple posttest. Dalam rancangan repetead measure seluruh partisipan dalam suatu kelompok tunggal berpartisipasi di semua pengukuran eksperimental, dimana setiap kelompok menjadi kontrolnya sendiri. Adapun langkahlangkah yang akan dilakukan dalam penelitian ini adalah sebagai berikut: (1) Pretest (T1) berupa pemberian instrumen pengumpulan data kepada kelompok eksperimen sebelum treatment. Adapun treatment dalam rancangan ini adalah perlakuan yang diberikan berupa pemberian konseling kelompok values clarification dengan teknik modelling; (2) Posttest pertama (T2) berupa pemberian instrumen pengumpulan data kepada kelompok eksperimen setelah treatment; dan (3) Post-test kedua (T3) berupa pemberian instrumen pengumpulan data, diberikan 1 minggu setelah post-test (T2) pada kelompok eksperimen.

Pengumpulan data dilakukan pada siswa kelas VII di Mts. Madrasatul Qur'aniyah, sebanyak 30 orang siswa yang diberikan kesempatan untuk mengisi instrument pre-test. Dari hasil assessment pretest diambil siswa yang memiliki nilai toleransi beragama rendah sesuai kriteria yang sudah ditentukan oleh peneliti dengan menggunakan teknik random assignment yang bertujuan untuk menjaga validitas internal. Adapun subjek penelitian yang terpilih sebanyak 5 orang siswa dikelompokan menjadi kelompok eksperimen dan diberikan intervensi berupa konseling kelompok values clarification dengan teknik modelling.

Lebih lanjut, dalam penelitian ini kelompok eksperimen mendapatkan delapan kali sesi konseling kelompok values clarification. Setiap sesi dari konseling kelompok values clarification dilakukan dengan durasi waktu selama 90 menit. Setelah pemberian intervensi konseling selesai, selanjutnya dilakukan assessment post-test pertama untuk melihat perubahan yang terjadi pada subjek penelitian. Adapun untuk memastikan intervensi yang diberikan memiliki dampak tetap terhadap subjek penelitian, maka peneliti melakukan assessment post-test kedua dengan rentang waktu satu minggu setelah dilakukannya assessement post-test pertama. Lebih lanjut, data yang sudah diperoleh dari hasil assessment dianalisis menggunakan repeated measures ANOVA.

\section{HASIL PENELITIAN DAN PEMBAHASAN}

Data yang dikumpulkan dalam penelitian ini adalah sikap toleransi antar umat beragama pada siswa di Mts. Madrasatul Qur'aniyah, Kabupaten Lombok Barat, Nusa Tenggara Barat. Data ini diperoleh dari siswa kelas VII yang berpartisipasi mengisi kuesioner sikap toleransi antar umat beragama. Lebih lanjut, yang menjadi partisipan dalam penelitian ini sebanyak 30 orang siswa. Berdasarkan hasil pengisian kuesioner dari seluruh siswa, diperoleh data berupa tingkat sikap toleransi antar umat beragama yang masuk dalam katagori tinggi, sedang dan rendah sesuai dengan kriteria yang sudah dibuat sebelumnya.

Berdasarkan data hasil assessment pretes, maka subjek dalam penelitian ini berjumlah 5 orang siswa yang memiliki kriteria sikap toleransi antar umat beragama rendah. Adapun nama-nama siswa dalam kelompok penelitian ini di tulis dalam tabel 1, dengan inisial agar tidak diketahui oleh orang lain dan nama baik mereka tetap terjaga.

Tabel 1. Hasil Pre-Test Kelompok Eksperimen

\begin{tabular}{|c|c|c|c|}
\hline No & $\begin{array}{c}\text { Nama Siswa } \\
\text { (Inisial) }\end{array}$ & Pre-Test & Kategori \\
\hline 1 & A & 32 & Rendah \\
\hline 2 & B & 32 & Rendah \\
\hline 3 & C & 34 & Rendah \\
\hline 4 & D & 32 & Rendah \\
\hline 5 & E & 34 & Rendah \\
\hline
\end{tabular}


Dari data yang sudah diperoleh dapat di lihat bahwa hasil assessment pre-test pada kelompok eksperimen menunjukkan sikap toleransi antar umat beragama rendah dengan angka interval 20 sampai dengan 39. Lebih lanjut, untuk meningkatkan sikap toleransi antar umat beragama siswa yang rendah tersebut, maka digunakan konseling kelompok values clarification dengan teknik modelling menggunakan video pendek sebagai alternatif pemecahan masalah.

Setelah melakukan proses konseling kelompok values clarification, maka selanjutnya yang dilakukan oleh peneliti adalah melakukan assessment post-test. Tujuan dilakukannya assessment post-test adalah untuk mengetahui perubahan tingkat sikap toleransi antar umat beragama siswa setelah diberikan intervensi. Adapun pengambilan data post-test dilakukan dengan menggunakan instrumen yang sama pada saat melakukan assessment pre-test. Berikut ini disajikan hasil assessment post-test dari kelompok eksperimen pada tabel 2.

Tabel 2. Hasil Post-Test Kelompok Eksperimen

\begin{tabular}{cccc}
\hline No & $\begin{array}{c}\text { Nama Siswa } \\
\text { (Inisial) }\end{array}$ & $\begin{array}{c}\text { Post }- \\
\text { Test }\end{array}$ & Kategori \\
\hline 1 & A & 54 & Sedang \\
2 & B & 54 & Sedang \\
3 & C & 56 & Sedang \\
4 & D & 56 & Sedang \\
5 & E & 54 & Sedang \\
\hline
\end{tabular}

Dari hasil assessment post-test di atas, terlihat ada perubahan skor yang menunjukkan terjadinya peningkatan sikap toleransi antar umat beragama pada subyek penelitian dari kategori rendah mejadi katagori sedang dengan interval 40 - 59. Adapun untuk memastikan perubahan yang terjadi pada subjek penelitian karena intervensi dari konseling kelompok values clarification teknik modelling dengan menggunakan video pendek maka peneliti kembali melakukan assessment follow-up satu minggu setelah assessment post-test dilakukan. Berikut ini disajikan hasil assessment follow-up dari kelompok eksperimen pada tabel 3.
Tabel 3. Hasil Follow-Up Kelompok Eksperimen

\begin{tabular}{cccc}
\hline No & $\begin{array}{c}\text { Nama Siswa } \\
\text { (Inisial) }\end{array}$ & $\begin{array}{c}\text { Follow- } \\
\text { Up }\end{array}$ & Kategori \\
\hline 1 & $\mathrm{~A}$ & 76 & Tinggi \\
2 & $\mathrm{~B}$ & 74 & Tinggi \\
3 & $\mathrm{C}$ & 74 & Tinggi \\
4 & $\mathrm{D}$ & 76 & Tinggi \\
5 & $\mathrm{E}$ & 74 & Tinggi \\
\hline
\end{tabular}

Dari hasil assessment follow-up di atas, terlihat adanya perubahan skor dimana terjadinya peningkatan sikap toleransi antar umat beragama menjadi kategori tinggi dengan interval $60-80$. Adapun setelah melakukan serangkaian assessment maka selanjutnya yang dikerjakan oleh peneliti adalah mencari nilai mean dan standar deviasi dari hasil assessment pre-test, post-test dan follow-up seperti dalam tabel 4.

Tabel 4. Hasil Mean Kelompok Eksperimen

\begin{tabular}{cccccccc}
\hline No & Inisial & $\begin{array}{c}\text { Pre- } \\
\text { test }\end{array}$ & Kategori & Post-test & Kategori & $\begin{array}{c}\text { Follow- } \\
\text { up }\end{array}$ & Kategori \\
\hline 1 & A & 32 & Rendah & 54 & Sedang & 76 & Tinggi \\
2 & B & 32 & Rendah & 54 & Sedang & 74 & Tinggi \\
3 & C & 34 & Rendah & 56 & Sedang & 74 & Tinggi \\
4 & D & 32 & Rendah & 56 & Sedang & 76 & Tinggi \\
5 & E & 34 & Rendah & 54 & Sedang & 74 & Tinggi \\
& Skor & 164 & & 274 & & 374 & \\
\multicolumn{2}{c}{$\begin{array}{l}\text { Mean } \\
\text { SD }\end{array}$} & 32.80 & & 54.80 & & 74.80 & \\
\hline
\end{tabular}

Dari penyajian data di atas, menunjukkan hasil pre-test $(\mathrm{M}=32.80, \mathrm{SD}=$ $1.09)$, post-test $(\mathrm{M}=54.80, \mathrm{SD}=1.09)$ dan follow-up $(\mathrm{M}=74.80, \mathrm{SD}=1.09)$. Lebih lanjut, untuk mengetahui hasil main effects (efek utama) dari kelompok eksperimen maka dapat di lihat dari hasil uji statistik repeated measures ANOVA. Adapun pada tabel 5, karakteristik deskriptif variabel sikap toleransi antar umat beragama disajikan.

Tabel 5. Karakteristik Deskriptif Sikap

Toleransi Antar Umat Beragama

\begin{tabular}{lcccccc}
\hline Kelompok & \multicolumn{6}{c}{ Pengukuran Sikap Toleransi } \\
\cline { 2 - 7 } & \multicolumn{3}{c}{$\mathrm{T}_{1}$} & \multicolumn{3}{c}{$\mathrm{T}_{2}$} \\
\cline { 2 - 7 } & $\mathrm{M}$ & $\mathrm{SD}$ & $\mathrm{M}$ & $\mathrm{SD}$ & $\mathrm{M}$ & $\mathrm{SD}$ \\
\cline { 2 - 7 } Eksperimen & 32.80 & 1.09 & 54.80 & 1.09 & 74.80 & 1.09 \\
$\mathrm{~F}_{1(2,6)}$ & & & & $1517.33, \mathrm{p}<0.01$ & & \\
\hline
\end{tabular}

Adapun hasil main effect dari time terhadap peningkatan sikap toleransi antar umat beragama pada kelompok eksperimen menunjukkan adanya pengaruh signifikan $(\mathrm{F}$ $(2,6)=1517.33, \mathrm{p}<0.01)$. Pengaruh dari time 
pada saat pengukuran menunjukkan terjadinya peningkatan sikap toleransi antar umat beragama pada kelompok eksperimen $\mathrm{T}_{1}(\mathrm{M}=$ 32.66, $\mathrm{SE}=0.43), \mathrm{T}_{2}(\mathrm{M}=54.83, \mathrm{SE}=0.56)$ dan $\mathrm{T}_{3}(\mathrm{M}=74.83, \mathrm{SE}=0.56)$.

Penelitian ini menyelidiki tentang keefektifan dari konseling kelompok values clarification teknik modeling untuk meningkatkan sikap toleransi antar umat beragama. Penelitian ini memberikan gambaran terkait dengan sikap toleransi antar umat beragama pada siswa remaja di Mts. Madrasatul Qur'aniyah, Kabupaten Lombok Barat, Nusa Tenggara Barat. Adapun hasil penelitian ini menegaskan bahwa konseling kelompok values clarification efektif dapat meningkatkan sikap toleransi antar umat beragama pada siswa di Mts. Madrasatul Qur'aniyah.

Hal ini sejalan dengan hasil penelitian yang dilakukan oleh Karmila (2013) yang mengungkapkan jika pendekatan values clarification efektif dalam meningkatkan nilainilai moral. Adapun nilai-nilai moral itu sendiri menekankan pada aspek kognitif, aspek afektif dan aspek psikomotor. Tujuan dari menanamkan nilai-nilai moral kepada individu adalah untuk membentuk pribadi yang mampu menggunakan akal dan perasaannya di dalam menimbang perilaku baik dan buruk yang berlandaskan nilai-nilai luhur, norma-norma agama, dan adat istiadat dalam kehidupannya.

Dalam hal ini, sikap toleransi antar umat beragama dilihat dari paradigma moral. Adapun toleransi antar umat beragama merupakan karakter dan bentuknya adalah pola pikir melalui refleksi diri, dialog terbuka, kesejukan, saling menghormati dan keharmonisan (Saihu, 2019). Lebih lanjut, toleransi dalam aspek moral merupakan wujud dari sikap menghormati ranah pribadi individu-individu yang berbeda. Menurut Mummendey \& Wenzel (1999) toleransi berkaitan erat dengan norma demokrasi seperti hak minoritas di dalam persamaan sosial. Jadi dalam hal ini, toleransi dapat dipahami sebagai sikap saling menghormati dan menghargai antar kelompok atau antar individu dalam masyarakat atau lingkup lainnya.
Lebih lanjut, berdasarkan hasil penelitian yang dilakukan oleh Lesievici \& Andronie (2016) mengungkapkan jika pendekatan values clarification efektif di dalam meningkatkan nilai-nilai moral siswa. Pendekatan values clarification juga dikatakan lebih efektif jika dibandingkan dengan menggunakan teknik tradisional. Selain efektif di dalam penerapannya pendekatan ini dapat meningkatkan motivasi dan dapat menciptakan lingkungan belajar yang menyenangkan. Dari beberapa hasil penelitian terdahulu maka dapat disimpulkan jika pendekatan values clarification efektif di dalam berbagai seting penelitian. Adapun di dalam penelitian ini pendekatan values clarification diterapkan melalui konseling kelompok dengan menyisipkan teknik modeling sebagai intervensinya.

Keefektifan dari konseling kelompok values clarification teknik modelling di tunjukkan dengan meningkatnya sikap toleransi antar umat beragama pada siswa di setiap pengukuran. Adapun peningkatan sikap toleransi antar umat beragama yang terjadi dimungkinkan karena pemberian teknik modeling yang dapat meningkatkan pemahaman individu melalui proses belajar mengobservasi tingkah laku model (orang lain) melalui video pendek yang berkenaan dengan perilaku-perilaku toleransi, seperti toleransi dalam kehidupan sehari-hari, tolong menolong, dan menjadi pribadi pemaaf.

Hasil penelitian ini memperkuat temuan sebelumnya yang menunjukan bahwa teknik modeling di dalam pendekatan values clarification sangat cocok digunakan sebagai intervensi di dalam membantu konseli meningkatkan nilai-nilai moralnya (Gunawan, Wibowo, Purwanto \& Sunawan, 2019). Adapun dengan menggunakan video pendek sebagai intervensi dapat dengan mudah mengarahkan siswa di dalam memahami perilaku baru. Pernyataan serupa juga diungkapkan oleh Widjayanto (2011) di mana penggunaan video dalam pembelajaran memudahkan siswa untuk memahami materi yang disampaikan, menciptakan rasa senang dalam mengikuti proses belajar, dan dapat menghindarkan diri dari rasa bosan. Lebih 
lanjut, penggunaan video visual dan audiovisual dapat membantu mempercepat pemahaman positif dan optimis pada pola pikir siswa terhadap lingkungan sekitarnya.

Adapun jika melihat nilai mean difference dari pairwise comparisons maka kelompok eksperimen yang diberikan konseling kelompok values clarification dengan teknik modelling di dalam meningkatkan sikap toleransi antar umat beragama pada siswa mengalami peningkatan pada setiap pengukurannya. Berdasarkan hasil analisis data, dapat di lihat perubahan sikap toleransi antar umat beragama pada kelompok ekperimen yang diberikan teknik modelling pada saat assessment pre-test menuju post-test $(\mathrm{MD}=-22.16, \mathrm{SE}=0.56, \mathrm{p}<0.01)$, pre-test menuju follow-up $(\mathrm{MD}=-42.16, \mathrm{SE}=0.93, \mathrm{p}$ $<0.01)$ dan post-test menuju follow-up (MD = $-20.00, \mathrm{SE}=0.74, \mathrm{p}<0.01$ ).

Hasil penelitian ini menunjukkan bahwa ada effect interactional time dari kelompok eksperimen terhadap peningkatan sikap toleransi antar umat beragama. Adapun treatmen dalam penelitian ini berupa konseling kelompok values clarification dengan teknik modelling yang diberikan pada kelompok eksperimen dikonseptualisasikan sebagai sebuah proses yang menyediakan pengalaman belajar di dalam mengarahkan anggota kelompok untuk merefleksikan kehidupan dan tindakan mereka terhadap orang lain yang berbeda agama. Hal ini menekankan bahwa konseling kelompok values clarification dengan teknik modelling merupakan salah satu pendekatan konseling yang mengutamakan aspek kognitif dan afektif di dalam menggali, memperjelas nilai-nilai serta menetapkan rencana tindakan selanjutnya.

\section{SIMPULAN}

Berdasarkan hasil analisis dalam penelitian, maka dapat ditarik kesimpulan sebagai berikut: (1) Konseling kelompok values clarification teknik modelling efektif di dalam meningkatkan sikap toleransi antar umat beragama siswa yang rendah; dan (2) Tingkat sikap toleransi antar umat beragama siswa semakin meningkat sesudah diberikan intervensi konseling values clarification teknik modelling.

\section{Saran}

Berdasarkan simpulan penelitian, maka saran ditujukan kepada berbagai pihak terkait yaitu: (1) bagi guru bimbingan dan konseling diharapkan dapat membantu meningkatkan sikap toleransi antar umat beragama pada siswa dengan menggunakan konseling kelompok values clarification khususnya menggunakan teknik modelling; dan (2) bagi peneliti selanjutnya diharapkan dapat menjadi refrensi untuk melakukan penelitian dalam seting yang berbeda.

\section{DAFTAR PUSTAKA}

Abdussami, H \& Tahir, M. (2003). Islam dan hubungan antar agama. Yogyakarta: LKiS.

Akbar, W. (2018). BIN ungkap 39 persen mahasiswa terpapar radikalisme. https://www.cnnindonesia.com/nasio nal.

Azwar, S. (2008). Penyususnan Skala Psikologi. Jakarta: Pustaka Pelajar.

Bahari. (2010). Toleransi beragama mahasiswa (Studi tentang pengaruh kepribadian, keterlibatan organisasi, hasil belajar pendidikan agama, dan lingkungan pendidikan terhadap toleransi mahasiswa berbeda agama pada 7 perguruan tinggi umum negeri). Badan Litbang dan Diklat Kementerian Agama RI.

Corey, G. (2012). Theory and practice of group counseling. California, Monterey: Brooks/Coley Publishing Company.

Creswell, J. (2015). Educational Research, Planning, Conducting, and Evaluating Quantitative and Qualitative. New Jersey: Pearson Education, Inc.

Djollong, A.F., \& Akbar, A. (2019). Peran guru pendidikan agama Islam dalam penanaman nilai-nilai toleransi antar ummat beragama peserta didik untuk mewujudkan kerukunan. Jurnal AlIbrah, 3, 72-92. 
Doorn V.M. (2014). The nature of tolerance and the social circumstances in which it emerges. Article sociology review. University Amsterdam, the Netherlands.

Gibson, JL (2006) Enigmas of intolerance: fifty yerasafter stouffer's communism, comformity, and civil liberties. Perspectives on politics 4(1): 21-34.

Gunawan, I.M.S. (2020). Meningkatkan kejujuran akademik mahasiswa melalui konseling kelompok values calrification. Jurnal Kependidikan, 6, 48-57.

Gunawan, I.M.S., Wibowo, M.E., Purwanto, E., \& Sunawan. (2019). Group counseling of values clarification to increase middle school student's empathy. Psicologia Educativa. 25 (2) $169-174$.

Hasyim, U. (1997). Toleransi dan kemerdekaan beragama dalam Islam sebagai dasar menuju dialog dan kerukunan antar agama. Surabaya: PT.Bina Ilmu.

Karmila, M. (2013). Implementasi pendekatan klarifikasi nilai atau values clarification technique (VCT) dalam pembelajaran moral pada anak usia dini. Jurnal Penelitian PAUDIA, 2, 126-141.

Kirschenbaum, (2000). From Values Clarification to Character Education:

A Personal Journey. Journal of Humanistic Counseling Education and Development, 39, 4-20.

Kirschenbaum, H. (2013). Values clarification in counseling and psychotrapy (Practical strategies for individual and group settings). New York: Oxford University Press.

Lesievici, P., \& Andronie, M. (2016). Teacher assessing the effectiveness of values clarification techniques in moral education. Procedia-Social and Behavioral Sciences, 217, 400-406.

Mujahidin, E., Rahman, I.K., \& Aqilah, F.N. (2020). Pendekatan bimbingan dan konseling Gestal Profetik (G-pro) untuk meningkatkan toleransi beragama siswa di SMA Ibnu 'Aqil. Jurnal Pendidikan Islam, 9, 99-126.

Mummendey, A., \& Wenzel, M. (1999). Social discrimination and tolerance in intergroup relations: reactions to intergroup difference. Pesonality and Social Psychology Review, 3, 1-10.

Munawar, S.A.H. (2003). Fikih hubungan antar agama. Jakarta: Ciputat Press.

Nuswantari. (2018). Model pembelajaran nilai-nilai toleransi untuk anak sekolah dasar. Jurnal University Research Colloqium, 1, 78-87.

Permana, D.S., Rachmat, N., \& Ismail, Y. (2014). Potret sikap toleransi beragama siswa (Studi kasus SMA Negeri 5 Jakarta Pusat Kelas XI). Jurnal Studi Al-Quran, 10, 168-177.

Pieterse, A.H., Vries, M., Kunneman, M., Stiggelbout, A.M., \& Steward, D.F. (2013). Theory-informed design of values clarification methods: A cognitive psychological perspective on patient health-related decision making. Journal Social Science \& Medicine, 77, 156-163.

Saihu. (2019). Pendidikan karakter berbasis kearifan lokal (studi di Jembrana Bali). Edukasi Islami, 8, 1-10.

Stewart, D.F., Tong, C., Siemens, R., Alibhai, S., Pickles, T., Robinson, J., \& Brundage, M.D. (2012). The impact of explicit values clarification exercises in a patient decision aid emerges after the decision is actually made: Evidence from a randomized controlled trial. Journal Medical Decision Making, 1, 616-626.

Sullivan JL, Piereson J and Marcus (1982) Political tolerance and democracy. Chicago: University of Chicago Press

Surur, A.M., Septiani, E., \& Trianawati, A.Y. (2018). Upaya menanamkan nilai religius siswa di MAN Kediri 1 Kota Kediri melalui ekstrakurikuler keagaman tahfidz Al-Qur'an. Jurnal Pendidikan Agama Islam, 15, 42-51. 
Utami, S.R. (2018). Implementasi nilai-nilai toleransi antar umat beragama pada lembaga pendidikan nonmuslim. Skripsi. Salatiga: IAIN Salatiga.

Wati, D.C., \& Arif, D.B. (2017). Penanaman nilai-nilai religious di sekolah dasar untuk penguatan jiwa profetik siswa. Prosiding Konferensi Nasional Kewarganegaraan III di Universitas Ahmad Dahlan Yogjakarta.

Widjayanto, P. (2011). Perasaan Senang dan Teori Motivasi Hedonisme Word Press.

http://www.putuwidjayanto.wordpres s.com/2011/01/14/teorimotivasihedonisme.

Widyaningsih, T.S., Zamroni \& Zuchdi, D. (2014). Internalisasi dan aktualisasi nilai-nilai karakter pada siswa smp dalam perspektif fenomenologis. Jurnal Pembangunan Pendidikan: Fondasi dan Aplikasi, 2, 181-195.

Witteman, et al. (2016). Design features of explicit values clarification methods: A systematic review. Journal Medical Decision Making, 1, 1-19. 